\title{
INDUSTRY CONCENTRATION AND THE CROSS-SECTION OF STOCK RETURNS: EVIDENCE FROM THE UK
}

\author{
Nawar HASHEM ${ }^{1}$, Larry SU $^{2}$ \\ ${ }^{1}$ Faculty of Economics, Damascus University, Almogtarebeen St., Damascus, Syria \\ ${ }^{2}$ School of Business, University of Greenwich, London SE10 9LS, UK \\ E-mails:1nhashem@hotmail.co.uk; ${ }^{2}$ l.su@gre.ac.uk (corresponding author)
}

Received 16 May 2013, accepted 07 Aug 2013

\begin{abstract}
In this paper, we examine the relationship between market structure and expected stock returns in the London Stock Exchange during 1985 and 2010. Using FamaMacBeth regressions, we find that industry concentration is negatively related to average stock returns, even after controlling for beta, size, book-to-market equity, momentum, and leverage. In addition, there is a strong evidence of a growth effect. Firms or industry portfolios with smaller book-to-market ratios have significantly higher returns. In contrast, beta is never statistically significant. The above results are robust to firm- and industrylevel regressions, and the formation of firms into 100 size-beta portfolios. Our findings indicate that competitive industries earn, on average, higher risk-adjusted returns than concentrated industries. An explanation is that investors in more competitive industries require larger premiums for greater distress risks associated with these industries. Our paper is one of the first to link market competition with the average stock returns in the UK, and contributes to the asset pricing literature by extending the evidence from the US to another important financial market.
\end{abstract}

Keywords: industry concentration, stock returns, market structure, distress risk, asset pricing, London stock exchange.

JEL Classification: G11, G12, L11.

\section{Introduction}

Prior research has uncovered a number of patterns in the cross-section of average stock returns, including the value premium, size effect, book-to-market equity effect and momentum effect. For example, Fama and French (1992) show that size and book-tomarket equity ratio capture the cross-section of returns much better than market beta. Fama and French (1993) further show that size, book-to-market equity and beta can explain the time-series performance of stock portfolios. Carhart (1997) finds that the momentum factor is important in explaining the cross-section of equity mutual fund returns. Lewellen (1999) finds that firm characteristics and macroeconomic variables predict significant time variation in expected returns on portfolios sorted by size and book-to-market equity ratio. Hou and Robinson (2006) argue that industry concentration 
affects the cross-section variation of stock returns. Because competitive industries are associated with more innovation and distress risks, investors in industries with strong competitive pressures will demand a positive return premium commensurate with the risk involved.

Given that the UK shares many similar characteristics with the US in terms of industry structure and market trading, it will be of interest to examine whether industry competitiveness affects the cross-section of UK stock returns in a manner consistent with that observed in the US. Specifically, the purpose of this paper is to address the following four research questions: First, is there a significant industry concentration premium in the UK stock market? In other words, do firms operating in more concentrated industries generate higher risk-adjusted returns? Second, are there significant differences in stock returns due to beta, size, book-to-market equity, momentum, and leverage? Third, does industry concentration premium remain significant after accounting for other risk factors? Fourth, is the relationship between industry structure and stock returns robust to firm-and industry-level regressions, and the formation of firms into various size-beta portfolios?

Using data for 1300 firms publicly listed in the London Stock Exchange (LSE) during 1985 and 2010, this paper finds that industry concentration is negatively related to expected stock returns in all Fama-MacBeth regressions, which is consistent with Hou and Robinson (2006) but against Gallagher and Ignatieve (2010). In addition, the negative relationship between industry concentration and expected stock returns remains significant, even after controlling for risk factors such as beta, size, book-to-market equity, momentum, and leverage. Furthermore, average stock returns are negatively related to book-to-market equity ratios and beta is never important in explaining the cross-section of stock returns in the UK. The above results are robust to firm- and industry-level regressions, and the formation of firms into 100 size-beta portfolios. Overall, the findings of this paper indicate that competitive industries earn, on average, higher returns compared to concentrated industries, in a manner that is consistent with higher distress risk faced by competitive industries.

The incremental contributions of our paper are three-fold. First, given that the literature remains inconclusive about the role of market structure in asset pricing, it is necessary to test the link between industry concentration and stock returns using a variety of samples. This paper provides one of the first country-specific studies extending the evidence from the US to cover an extensive and more recent period in the UK. Second, extant studies on the behaviour of asset prices in the UK have not considered industry structure as a potential source of risk. This paper is one of the first to link market competition with the average stock returns in the UK. Third, prior research on the cross-section of UK stock returns predominantly uses portfolio returns formed on firm characteristics. This paper examines whether market structure helps to explain the observed differences in average stock returns using both firm- and industry-level regressions.

The rest of the paper is organised as follows. Section 1 briefly reviews the literature on empirical asset pricing. Section 2 describes the data and presents descriptive statistics 
on measures of industry concentration. Section 3 reports industry average characteristics across industry concentration quintile portfolios and the correlation between industry concentration and industry characteristics. Section 4 applies Fama-MacBeth regressions to examine the relationship between industry concentration and the cross-section of stock returns using firm- and industry-level regressions and 100 size-beta portfolios. The last section summarizes the findings and discusses some unresolved issues for future research.

\section{Literature review}

Prior research into the determinants of the cross-sectional variation in average stock returnshas uncovered a large number of anomaliesthat are inconsistent with rational asset pricing theories. For example, Fama and French (1992) demonstrate that firm size and book-to-market can explain the cross-section of stock returns, while beta has no explanatory power. Jegadeesh (1990), Jegadeesh and Titman (1993) find that stocks with higher returns during the previous few months tend to have higher future returns (short-term momentum). Fama and French (1993) find that a three factor-model including size, value, and beta can capture the time-series variation in stock returns. Carhart (1997) augments the three-factor model to include a momentum factor and finds that the four-factor model can better explain the cross-section of stock returns.

However, Daniel and Titman (1997) raise further controversy on multifactor asset pricing models by arguing that firm characteristics, rather than factor loadings, determine the cross-sectional variation of expected returns. They find no significant return premium associated with any of the Fama-French three factors during the period between 1973 and 1993 in the US. Hawanini and Keim (2000) document that many anomalies such as the size effect, the value effect and the dividend yield effect appear to be only significant during the month of January, and casts doubt on the risk-based multifactor models. Davis et al. (2000) show that covariances (sensitivities of returns to factors) have more explanatory power than characteristics during 1929 and 1997. Chou et al. (2004) find that the predictive ability of size and book-to-market equity diminishes for the periods 1982 to 2001 and 1990 to 2001, respectively. Hou and Robinson (2006) test the link between average stock returns and market structure, and finds that firms in concentrated industries earn significantly lower return than those in competitive industries. However, Gallagher and Ignatieve (2010) and Gallagher et al. (2014) document that Australian firms in concentrated industries earn, on average, higher risk-adjusted returns compared to those in competitive industries.

In recent years, there has been a growing literature on empirical asset pricing in the UK stock markets. For instance, Miles and Timmermann (1996) find that book-to-market equity ratio is positively related to the cross-section of stock returns, and both size and book-to-market equity risk premiums can predict up to $20 \%$ of the time-series variation in the monthly stock returns. Strong and Xu (1997) find that book-to-market equity ratio and leverage can explain the cross-section of stock returns during 1973 and 1992, while beta and firm size have no explanatory power. Liu et al. (1999) report the pres- 
ence of momentum profits during 1977 and 1998, which cannot be explained by firm size, book-to-market equity ratio and cash earnings-to-price ratio. Gregory et al. (2001) document significant value premiums during 1975 and 1998, and that the Fama-French three-factor model cannot explain excess returns on value strategies using portfolios formed on past sales growth and book-to-market value. Dimson et al. (2003) find that the UK firms with high dividend yields outperform those with low dividend yields. Hon and Tonks (2003) provide evidence that momentum strategies are only profitable from 1977 onwards, while the momentum effect disappears prior to 1977. Hung et al. (2004) show that both the CAPM and Fama-French three-factor model hold in the UK stock market, and that book-to-market effect dominates the size effect. Michou et al. (2007) survey various sorting methods to construct size and book-to-market mimicking portfolios, and casts doubt on the predictive ability of the Fama-French three-factor model to estimate abnormal stock returns in the UK. Chen and Hill (2013) find that default risk is a significant determinant of stock returns and this relationship is "hump backed", as predicted by Garlappi and Yan (2011). Foran et al. (2015) find that systematic liquidity risk is positively priced in the cross-section of UK stocks, specifically for the quoted spread liquidity measure.

Although the aforementioned research has provided important evidence on the ability of multifactor models in explaining stock returns in the UK, a number of issues remain to be further explored. For example, the ultimate success of multifactor models depends on the ability of the model to capture risk completely, but prior research on the UK stock market has not considered industry structure as a source of risk, which may induce errors in variables (EIV) problem in empirical analyses. Moreover, existing studies on the UK stock market often discover inconsistent evidence on the relative importance of size, book-to-market, momentum, leverage and beta in explaining the cross-section of expected returns. It will be worthwhile to examine whether various sets of risk factors remain statistically and economically significant after industry competition is accounted for. Furthermore, different methods of estimating factor risk premiums can lead to quite different characteristics in asset pricing relationship. Therefore, it is important to test the multifactor models using a variety of risk measures and regression techniques.

\section{Data and the measurement of industry concentration}

\subsection{Data}

The sample used in this study is an unbalanced panel consisting of 1300 companies publicly listed in the LSE during 1985 and 2010. Data stream classifies each company into an industry based on the firm's primary business activity published by the FTSE Actuaries. There are a total of six levels of industrial classifications. Throughout this paper, we use the most detailed level 6 classification consisting of 88 industries. Appendix provides a description of industry classification.

Consistent with prior studies, we exclude de-listed companies, financial companies (banks, investment trusts, insurance companies, and properties companies), companies that have more than one classification of ordinary shares, and companies with negative 
book-to-market-ratio. To ensure that stock prices for listed companies reflect prior accounting information, we extract data on market value of equity, book-to-market ratio, leverage, total assets, and net sales at the end of the fiscal year $t-1$. We then match stock returns data from July of year $t$ to June of year $t+1$ with accounting information for fiscal year ending in $t-1$. In addition, to allow estimation of market beta and postranking beta, we require a company to have monthly return data during the previous 3-5 years.

For every sample company in each year, we collect information on the following firmspecific characteristics and accounting variables: (1) SIZE is the end-of-year market value of equities; (2) $B / M$ is the book value divided by the market value of common equity; (3) $L E V$ is the ratio of total debt and equity; (4) ASSETS is the book value of total assets; (5) SALES is net sales revenue; (6) $R \& D$ is research and development expense; (7) $R \& D / A$ is the ratio of $R \& D$ and total assets.

To calculate the post-ranking beta (PBETA), we obtain monthly firm- or industry-level returns or returns from 100 size-beta portfolios constructed based on the methodology of Fama and French (1992) during year $t$ and $t+1$. We then regress the monthly stock/ industry/portfolio returns on market returns over the 12-month period. Finally, we assign the post-ranking beta to each stock/industry/portfolio on an yearly basis so that it has the same beta within the 12-month period.

\subsection{Measures of industry concentration}

Consistent with Hou and Robinson (2006), Gallagher and Ignatieve (2010), we use the Herfindahl-Hirschman index to measure industry concentration as follows:

$$
H_{j}=\sum_{i=1}^{M} S_{i j}^{2}
$$

where $S_{i j}$ represents the market share of firm $i$ in industry $j$ for a given year, and $M$ is the number of firms in industry $j$. For robustness, we compute $S_{i j}$ based on net sales, book value of total assets, and book value of equity, respectively. Thus we have three types of Herfindahl index denoted as $H_{-} S A L E S, H \_$ASSETS and H_EQUITY. If an industry is concentrated/competitive, the market shares are distributed to a small/large number of firms and the value of the Herfindahl index will be large/small. We calculate $H_{j}$ every year for each industry, and then average the values over the previous three years to reduce potential errors in measuring industry concentration.

\subsection{Descriptive statistics}

Table 1 presents summary statistics of three measures of industry concentration for 88 industries between 1985 and 2010. As shown in the table, the average firm in our sample belongs to an industry with mean (median) H_SALES of0.3984 (0.3345), H_ASSETS of $0.3852(0.3144)$ and $H_{-} E Q U I T Y$ of $0.3710(0.2987)$, which are all lower than the 0.544 (0.490), 0.549 (0.499) and 0.546 (0.502) reported in Hou and Robinson (2006). The results indicate that our sample of the UK firms during 1985 and 2010 face more competition than the sample of US firms during 1962 and 2001. 
Although $H \_S A L E S$ is on average higher than the other two measures of industry concentration, it has the lowest standard deviation. In addition, the spread in industry concentration is large. The most competitive deciles (lowest $10 \%$ ) has an average $H \_S A L E S$ of 0.1145 , while the most concentrated deciles (top 90\%) has an average of 0.8438 . Furthermore, the Spearman-Pearson correlation matrix indicates that all three measures of industry concentration are highly correlated with each other. The correlation coefficient between $H \_A S S E T S$ and $H \_E Q U I T Y$ is the largest while the correlation coefficient between $H_{-} S A L E S$ and $H_{-} E Q U I T Y$ is the smallest.

\section{Industry concentration and industry characteristics}

\subsection{Industry average characteristics and concentration quintiles}

Table 2 reports average firm- and industry-level returns as well as average industry characteristics for each quintile portfolio constructed based on the values of their H_SALES. We calculate industry returns at industry level and other characteristics at the firm level, and then average them within each quintile portfolio.

An inspection of the table reveals several interesting findings. First, the mean firmand industry-level returns decrease from Q1 to Q5, suggesting that firms in low concentration quintiles earn, on average, higher returns than those in high concentration quintiles. The spread in the average firm-level returns between the lowest and highest concentration quintiles is approximately $0.22 \%$ per month, or $2.64 \%$ per annum. The spread based on the average industry-level returns for the lowest and highest $H \_S A L E S$ quintiles is approximately $0.21 \%$ per month, or $2.52 \%$ per annum. The results are consistent with our conjecture that competitive industries earn, on average, higher returns than concentrated industries. Second, the average firm size, total assets and net sales for concentrated industries are significantly higher than those for competitive industries. Third, the average $R \& D$ expenditure increases from $£ 3.64$ million for the least concentrated quintile to reach a dramatic $£ 92.5$ million for quintile 4 , and then decreases to $£ 46.78$ million for the most concentrated quintile. Scaling by total assets leads to the same pattern. The results suggest that firms in more competitive industries spend less on innovations.

Finally, firms in the most competitive industries have larger book-to-market equity ratios than those in the most concentrated industries, but there is little differences in leverage ratios across various industry concentrations quintiles. There is no evidence that firms in competitive industries are more risky than those in concentrate industries, because the average post-ranking beta rises from 0.7934 for quintile 1 to 0.8444 for quintile 2, falls to 0.7704 for quintile 4 , and then rises to 0.8539 for quintile 5 . 

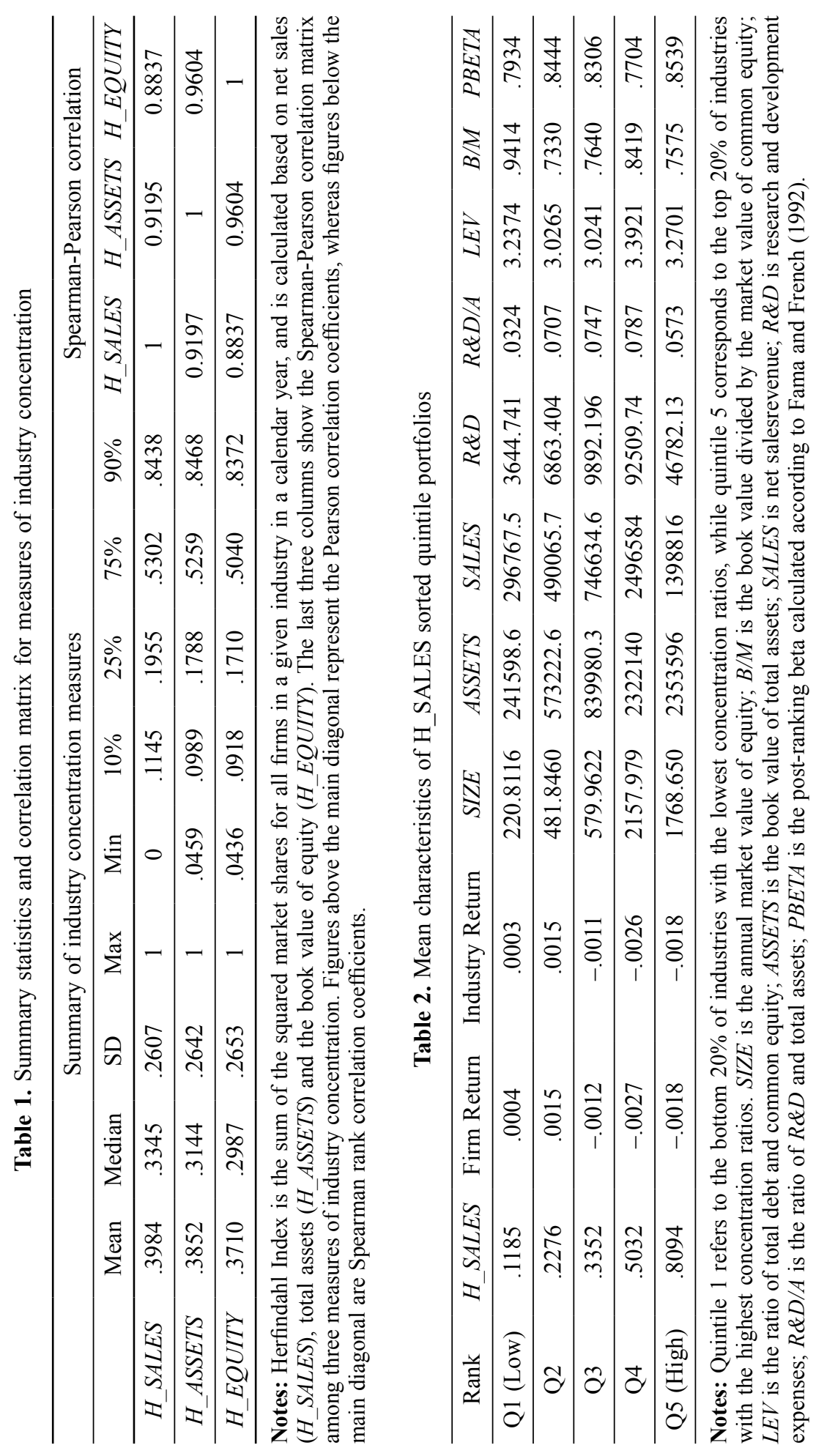


\subsection{Regressions of industry concentration on industry average characteristics}

To explore the relationship between industry concentration and industry average characteristics more fully, we adopt the Fama-MacBeth (1973) approach and conduct our empirical analysis in two steps. In the first step, we estimate the following cross-section regression for each year from 1985 to 2010 :

$$
H_{-} S A L E S_{j, t}=\alpha_{t}+\sum_{k=1}^{K} \beta_{k, t} X_{k, j, t}+\varepsilon_{j, t},
$$

where $H \_S A L E S_{j, t}$ is the Herfindahl index based on net sales for industry $j$ in year $t$, $X_{k, j, t}$ denotes industry average characteristics, including LNSIZE, LNASSETS, LNSALES, $R \& D / A, L E V, L N B / M$ and PBETA. In the second step, we compute the time-series average of the coefficient estimates as well as their $t$-statistics. Table 3 contains estimation results from the Fama-MacBeth two-step procedure.

As shown in Table 3, firm size, total assets, and net sales are positively related to industry concentration, as the coefficient estimates for LNSIZE, LNASSETS and LNSALES are individually significant at the $1 \%$ level, with or without other characteristic

Table 3. Fama and MacBeth regressions of industry concentration on industry average characteristics

\begin{tabular}{|c|c|c|c|c|c|c|}
\hline \multicolumn{7}{|c|}{ Panel A: simple regressions } \\
\hline LNSIZE & LNASSETS & LNSALES & $R \& D / A$ & $L E V$ & $L N B / M$ & PBETA \\
\hline .01453 & .0119 & .0030 & -.0352 & .0079 & -.01570 & .0030 \\
\hline $28.55 *$ & $19.09 *$ & $5.31 *$ & -0.80 & $11.72 *$ & $-17.95 *$ & $3.07 *$ \\
\hline \multicolumn{7}{|c|}{ Panel B: multiple regressions } \\
\hline \multirow[t]{3}{*}{ LNSIZE } & LNASSETS & LNSALES & $R \& D / A$ & $L E V$ & $L N B / M$ & PBETA \\
\hline & & & -.0855 & .01486 & -.0399 & -.0020 \\
\hline & & & $-2.37 *$ & $11.97 *$ & $-15.18 *$ & -0.58 \\
\hline .0277 & & & .0451 & .0066 & -.0266 & -.0333 \\
\hline \multirow[t]{5}{*}{$39.31^{*}$} & & & 0.99 & $5.73^{*}$ & $-10.03 *$ & $-6.83^{*}$ \\
\hline & .0266 & & .0931 & .0022 & -.0444 & -.0308 \\
\hline & $36.36^{*}$ & & $2.01 * *$ & $1.8^{* * *}$ & $-16.39 *$ & $-6.30^{*}$ \\
\hline & & .0202 & .0617 & .0052 & -.0437 & -.0275 \\
\hline & & $24.69 *$ & 1.34 & $4.25^{*}$ & $-15.62 *$ & $-5.64 *$ \\
\hline .0110 & .0790 & -.0657 & -.0432 & -.0010 & -.04217 & -.0359 \\
\hline $2.92 *$ & $8.39 *$ & $-9.66^{*}$ & -0.80 & -0.43 & $-10.64 *$ & $-7.60 *$ \\
\hline
\end{tabular}

Notes: Panel A contains results from bivariate cross-sectional regressions of industry concentration on each of the 7 industry characteristics. Panel B contains results from multiple cross-sectional regressions of industry concentration on a group of characteristic variables. LNSIZE, LNASSETS, and LNSALES are the logarithms of average firm size, total assets, and net sales, respectively. $R \& D / A$ is the ratio between $\mathrm{R} \& \mathrm{D}$ expenses and total assets. $L E V, L N B / M$, and PBETA are leverage, the logarithm of book-to-market equity ratio, and post ranking beta, respectively. Numbers in italics are $t$-statistics. $*, * *$, and $* * *$ denote statistically significant at the $1 \%, 5 \%$ and $10 \%$ level, respectively. 
variables. When we include all 7 variables in one regression, LNSIZE and LNASSETS remain significantly positive, while $L N S A L E S$ becomes significantly negative, all at the $1 \%$ level. The results suggest that firms in concentrated industries have higher market value of equity, book value of assets and net sales than those in competitive industries. In addition, the coefficient estimates for $L E V$ are significantly positive at the $1 \%$ level in all but the last regressions, and the coefficient estimates for $L N B / M$ are significantly negative at the $1 \%$ level in all regressions. Therefore, industry concentration is positively related to leverage but negatively related to book-to-market equity, indicating that firms in concentrated industries have higher market value of equity and use more debt than those in competitive industries. Finally, the coefficient estimates for PBETA are significantly positive at the $1 \%$ level in simple regressions, but are significantly negative at the $1 \%$ level in most of the multiple regressions. Taken together, firms in concentrated industries appear to be less risky than those in the competitive industries.

\section{Industry concentration and the cross-section of stock returns}

\subsection{Empirical results based on firm-level regressions}

To examine the relationship between industry concentration and the cross-section of stock returns, we implement Fama-MacBeth regressions of monthly individual stock returns on Herfindahl index (based on net sales) and other firm-specific characteristics. In particular, we estimate the following cross-section regression each month from 1985 to 2010 :

$$
\begin{aligned}
& R_{i}=\gamma_{0}+\gamma_{1} H_{-} \text {SALES }_{i}+\gamma_{2} \text { LNSIZE }_{i}+\gamma_{3} L N B / M_{i}+ \\
& \gamma_{4} \text { MOMENTUM }_{i}+\gamma_{5} \text { PBETA }_{i}+\gamma_{6} L E V_{i}+u_{i},
\end{aligned}
$$

where the subscript $i$ denotes firm-level data and the number of companies is 1300; $\operatorname{MOMENTUM}_{i}$ is the past one-year return for each firm; firms within the same Data stream level-6 industry have the same $H \_S A L E S$. We then compute time-series average slope coefficient estimates and their $t$-statistics. Table 4 presents estimation results from Fama-MacBeth regressions of firm-level returns.

As shown in the table, the time-series average coefficient estimates for $H_{-} S A L E S$ are negative and statistically significant at the 5\% level, implying that companies operating in concentrated industries earn, on average, lower risk-adjusted returns compared to those operating in competitive industries. The results echo our findings in Section 3.1 in that the mean value of stock returns decreases from the least concentration quintile to the highest concentration quintile. An explanation is that firms in concentrated industries face less competition and less distress risks compared with those in competitive industries.

In addition, there is strong evidence that average stock returns are negatively related to book-to-market equity ratio, as the average coefficient estimates for $L N B / M$ are all significantly negative at the $1 \%$ level, with or without controlling for other firm characteristics. The results are consistent with Malin and Veeraraghavan (2004), which documents a significant growth effect in the UK stock market. 
Table 4. Fama-MacBeth regressions of firm-level returns

\begin{tabular}{|c|c|c|c|c|c|}
\hline H_SALES & LNSIZE & $L N B / M$ & MOMENTUM & PBETA & $L E V$ \\
\hline \multicolumn{6}{|l|}{$\begin{array}{c}-.0037 \\
-2.03 * *\end{array}$} \\
\hline & $\begin{array}{c}.0007 \\
1.34\end{array}$ & & & & \\
\hline & & $\begin{array}{l}-.0064 \\
-7.22 *\end{array}$ & & & \\
\hline & & & $\begin{array}{l}.0046 \\
1.32\end{array}$ & & \\
\hline & & & & $\begin{array}{c}-.0025 \\
-.84\end{array}$ & \\
\hline & & & & & $\begin{array}{c}-.0008 \\
-2.43 * *\end{array}$ \\
\hline & $\begin{array}{l}.0004 \\
1.00\end{array}$ & $\begin{array}{l}-.0069 \\
-7.69^{*}\end{array}$ & $\begin{array}{l}.0043 \\
1.25\end{array}$ & $\begin{array}{l}-.0040 \\
-1.28\end{array}$ & $\begin{array}{l}-.0015 \\
-4.89 *\end{array}$ \\
\hline $\begin{array}{l}-.0050 \\
-2.76^{*}\end{array}$ & $\begin{array}{c}-.0001 \\
-0.26\end{array}$ & $\begin{array}{l}-.0068 \\
-7.09 *\end{array}$ & $\begin{array}{l}.0036 \\
1.05\end{array}$ & & \\
\hline $\begin{array}{c}-.0037 \\
-2.06^{* *}\end{array}$ & $\begin{array}{c}.0005 \\
1.14\end{array}$ & $\begin{array}{l}-.0069 \\
-7.78^{*}\end{array}$ & $\begin{array}{c}.0039552 \\
1.14\end{array}$ & $\begin{array}{c}-.0041 \\
-1.32\end{array}$ & $\begin{array}{l}-.0015 \\
-4.96^{*}\end{array}$ \\
\hline
\end{tabular}

Notes: This table reports Fama and MacBeth (1973) regression of individual stock returns on H_SALES and firm-specific characteristics. Monthly individual firms' returns are regressed on H_SALES of the industry which the firm belongs to, and firms-specific characteristics such as LNSIZE, $L \bar{N} B / M$, and MOMENTUM (past 12 months stock returns), LEV, and PBETA. Cross-sectional regressions are estimated monthly and the time-series $t$-statistics appear in italic under the time-series average coefficient estimates of the monthly cross-section regressions. ${ }^{*}, * *$, and $* * *$ denote statistically significant at the $1 \%, 5 \%$ and $10 \%$ level, respectively.

Moreover, highly levered firms earn, on average, significantly lower returns than low leverage firms, as the coefficient estimates for $L E V$ are all significantly negative at the 5\% level. The results are consistent with Sivaprasad and Muradoglu (2009), which report significantly negative relationship between leverage and stock returns in the UK. Finally, firm size, momentum and post-ranking beta are unrelated to the cross-section of firm-level returns, as none of the average coefficient estimates for LNSIZE, MOMENTUM and PBETA is statistically significant. The results are consistent with many existing studies of the UK stock market (see, for instance, Miles and Timmermann 1996; Strong and Xu 1997; Al-Horani et al. 2003; among others). In contrast, Hou and Robinson (2006) document negative firm size effect and positive momentum effect in the US stock markets. Gallagher and Ignatieve (2010) show that average stock returns are positively related to size and market beta, while unrelated to momentum in Australia.

\subsection{Empirical results based on industry-level regressions}

To shed more light on the relationship between industry concentration and stock returns, we conduct Fama-MacBeth regressions of monthly industry-level returns on $H \_S A L E S$ 
and other industry characteristics. The cross-section regression is as follows:

$$
\begin{aligned}
& R_{j}=\varphi_{0}+\varphi_{1} H_{-} S_{A L E S_{j}}+\varphi_{2} \text { LNSIZE }_{j}+\varphi_{3} L N B / M_{j}+ \\
& \varphi_{4} \text { MOMENTUM }_{j}+\varphi_{5} \text { PBETA }_{j}+\varphi_{6} L E V_{j}+u_{j},
\end{aligned}
$$

where the subscript $j$ denotes industry-level data and the number of industries is 88 . Table 5 contains time-series average slope coefficient estimates and their $t$-statistics from Fama-MacBeth regressions of industry average returns.

\begin{tabular}{|c|c|c|c|c|c|}
\hline H_SALES & LNSIZE & $L N B / M$ & MOMENTUM & PBETA & $L E V$ \\
\hline \multicolumn{6}{|l|}{$\begin{array}{c}.0037 \\
-2.02 * *\end{array}$} \\
\hline & $\begin{array}{l}.00103 \\
2.18^{* *}\end{array}$ & & & & \\
\hline & & $\begin{array}{l}-.0048 \\
-3.28^{*}\end{array}$ & & & \\
\hline & & & $\begin{array}{l}.02662 \\
3.07 *\end{array}$ & & \\
\hline & & & & $\begin{array}{c}-.0044 \\
-1.26\end{array}$ & \\
\hline & & & & & $\begin{array}{l}.0004 \\
0.47\end{array}$ \\
\hline & $\begin{array}{l}.0007 \\
1.49\end{array}$ & $\begin{array}{l}-.0044 \\
-3.12 *\end{array}$ & $\begin{array}{l}.0181 \\
2.34 * *\end{array}$ & $\begin{array}{c}-.0040 \\
-1.15\end{array}$ & $\begin{array}{c}-.0007 \\
0.97\end{array}$ \\
\hline $\begin{array}{l}-.0051 \\
-2.81^{*}\end{array}$ & $\begin{array}{l}.0007 \\
1.31\end{array}$ & $\begin{array}{l}-.0046 \\
-2.81^{*}\end{array}$ & $\begin{array}{c}.0219 \\
2.55 * *\end{array}$ & & \\
\hline $\begin{array}{c}-.0044 \\
-2.50 * *\end{array}$ & $\begin{array}{c}.0009 \\
1.85 * * *\end{array}$ & $\begin{array}{l}-.0045 \\
-3.27^{*}\end{array}$ & $\begin{array}{c}.0159 \\
2.05 * *\end{array}$ & $\begin{array}{c}-.0044 \\
-1.26\end{array}$ & $\begin{array}{c}-.0006 \\
-0.98\end{array}$ \\
\hline
\end{tabular}

Table 5. Fama-MacBeth regressions of industry-level returns

Notes: This table reports Fama and MacBeth (1973) regression of industry-level returns on H_SALES and industry average characteristics. Monthly industry average returns are regressed on industry average values of LNSIZE, LNB/M, LEV, and PBETA as well as industry H_SALES index, and the past one year industry portfolio returns MOMENTUM. Cross-sectional regressions are estimated monthly and the time-series t-statistics appear in italic under the time-series average coefficient estimates of the monthly cross-section regressions. ${ }^{*}, * *$, and $* * *$ denote statistically significant at the $1 \%, 5 \%$ and $10 \%$ level, respectively.

As shown in the table, consistent with firm-level results, the time-series average coefficient estimates for $H_{-} S A L E S$ remain significantly negative at the 5\% level, suggesting that concentrated industries earn significantly lower returns than competitive industries. The average coefficient estimates for $L N B /$ Mare significantly negative at the $1 \%$ level, providing strong evidence of a growth effect for the UK industries. The average coefficient estimates for PBETA remain statistically insignificant, indicating that market risks are not priced for the cross-section of industry returns. 


\subsection{Empirical results using beta estimates based on 100 size-beta portfolios}

To further examine the robustness of our results, we calculate post-ranking beta (PBETA) using 100 size-beta portfolios based on the methodology of Fama and French (1992), and conduct Fama-MacBeth regressions of monthly individual stock returns on industry-level H_SALES, portfolio-level PBETA and firm-level characteristic variables. In particular, we first sort individual companies according to their firm size into 10 deciles in year $t$. For each size group, we further sort companies according to their pre-ranking beta into 10 deciles. The intersection between 10 size portfolios and 10 beta portfolios gives 100 size-beta portfolios. We then calculate the post-ranking average monthly returns for each of the 100 size-beta portfolios from year $t$ to year $t+1$. We repeat the aforementioned steps in each year for the whole sample period, and estimate the postranking betas for each of the 100 size-beta portfolios by regressing the post-ranking average monthly portfolio returns on market returns over the full sample period. For all monthly Fama-MacBeth cross-section regressions, we assign each firm in every 100 size-beta portfolios during entire year $t a$ post-ranking portfolio beta corresponding to the firm's portfolio group. Finally, we estimate cross-section regression (3) each month over the entire sample period. Table 6 contains time-series average slope coefficient estimates and their $t$-statistics from Fama-MacBeth regressions of portfolio average returns.

Table 6. Fama-MacBeth regressions of returns on 100 size-beta portfolios

\begin{tabular}{|c|c|c|c|c|c|}
\hline$H \_S A L E S$ & LNSIZE & $L N B / M$ & MOMENTUM & PBETA & $L E V$ \\
\hline \multicolumn{6}{|l|}{$\begin{array}{c}-.0037 \\
-2.03 * * \\
\end{array}$} \\
\hline & $\begin{array}{l}.0006 \\
1.34 \\
\end{array}$ & & & & \\
\hline & & $\begin{array}{l}-.0064 \\
-7.22 * \\
\end{array}$ & & & \\
\hline & & & $\begin{array}{l}.0046 \\
1.32 \\
\end{array}$ & & \\
\hline & & & & $\begin{array}{c}-.0034 \\
-1.19\end{array}$ & \\
\hline & & & & & $\begin{array}{c}-.0008 \\
-2.43 * * \\
\end{array}$ \\
\hline & .0004 & -.0068 & .0052 & -.0041 & -.0013 \\
\hline & 1.02 & $-7.62 *$ & 1.51 & -1.44 & $-4.35 *$ \\
\hline-.0050 & -.0001 & -.0068 & .0036 & & \\
\hline$-2.76^{*}$ & -0.26 & $-7.09 *$ & 1.05 & & \\
\hline-.0042 & .0005 & -.0068 & .0048 & & -.0013 \\
\hline$-2.37 * *$ & 1.18 & $-7.70 *$ & 1.39 & & $-4.39 *$ \\
\hline
\end{tabular}

Notes: This table reports Fama and MacBeth (1973) regression of firm-level stock returns on $H$ $S A L E S$, post-ranking beta (PBETA) formed by 100 size-beta portfolios according to Fama and French (2002), and firm-specific characteristic variables. Monthly individual firms' returns are regressed on $H \_S A L E S$ of the industry to which the firm belongs, PBETA, and firms-specific characteristics such as $L N S I Z E$, $L N B / M$, and MOMENTUM and $L E V$. Cross-sectional regressions are estimated monthly and the time-series $t$-statistics appear in italic under the time-series average coefficient estimates of the monthly cross-section regressions. ${ }^{*}, * *$, and $* * *$ denote statistically significant at the $1 \%, 5 \%$ and $10 \%$ level, respectively. 
As shown in the table, the results from portfolio-level regressions are almost identical to those from firm-level regressions. In particular, the time-series average coefficient estimates for $H \_S A L E S$ are significantly negative at the 5\% level with or without other characteristic variables, suggesting that average portfolio returns decrease in industry concentration. The average coefficient estimates for $L N B / M$ and $L E V$ are all significantly negative, confirming the presence of growth effect and leverage effect in the UK stock market.

\section{Conclusions}

In this paper, we empirically examine the relationship between market structure and the cross-section of expected stock returns in the UK stock market. Using data of 1300 companies publicly listed in the LSE during 1985 and 2010, we find that industry concentration is negatively related to the average stock returns in all Fama-MacBeth regressions. In fact, the inclusion of existing risk factors such as beta, firm size, bookto-market, momentum, and leverage does not ruin the ability of industry concentration in explaining the cross-section of average stock returns. Rather, the relationship appears to be strong. The relationship is also robust to firm- and industry-level regressions and the formation of firms into 100 size-beta portfolios. There is a strong evidence that investors of competitive industries in the UK stock market require higher risk premiums to compensate for greater distress risks associated with these industries.

Relying on the structure-conduct-performance (SCP) paradigm in industrial organization, we can provide two risk-based explanations on our findings. First, concentrated industries engage less in innovations and face lower innovation risk compared with competitive industries. Second, concentrated industries have higher barriers to entry, which protects their firms from distress risk. Therefore, investors should anticipate lower risk-adjusted stock returns associated with lower innovation and distress risks in concentrated industries.

The implications for our results are three folds. First, industry structure plays a pivotal role in determining the cross-section of asset returns in the UK. Excess stock returns are compensation for the increased risk to corporate cash flows associated with more intensive market competition. Second, while there is a strong documented value effect for the US stocks, shares in the UK market exhibit significant growth effect. Investors in the UK may have bought growth stocks (low book-to-market stocks) for their high earnings potentials, but overestimated the earnings and performance of this type of assets. Thus, growth stocks are actually more risky than value stocks. Third, while there are negative size effect and positive momentum effect in the US stock markets, firm size and momentum are unrelated to the cross-section of firm-level returns in the UK. The results indicate that large firms dominate concentrated industries and small firm premium can be subsumed by concentration premium.

Although we obtain some interesting findings in this paper, several extensions remain possible. First, it should be of interest to investigate whether industry concentration premium can explain the time-series variation of stock returns in the UK. Second, a major 
limitation is that we only use Herfindahl index based on net sales to measure industry concentration, which can be imprecise especially when survivorship bias and sample selection bias are present. It might be necessary to use other measures such as entropy index and Lerner index to test the robustness of our results. Third, the sample used in this study only covers firms listed in the LSE. Further research can use more distinctive data under other institutional settings.

\section{References}

Al-Horani, A.; Pope, F. E.; Stark, A. W. 2003. Research and development activity and expected returns in the United Kingdom, European Finance Review 7: 27-46.

http://dx.doi.org/10.1023/A:1022504029943

Carhart, M. 1997. On persistence of mutual fund performance, Journal of Finance 52: 57-82. http://dx.doi.org/10.1111/j.1540-6261.1997.tb03808.x

Chen, J.; Hill, P. 2013. The impact of diverse measures of default risk on UK stock returns, Journal of Banking and Finance 37: 5118-5131. http://doi:10.1016/j.jbankfin.2013.06.013

Chou, P. H.; Chou, R. K.; Wang, J. S. 2004. On the cross-section of expected stock returns: Fama-French ten years later, Finance Letters 2: 18-22.

Daniel, K.; Titman, S. 1997. Evidence on the characteristics of cross-sectional variation in stock returns, Journal of Finance 52: 1-33. http://dx.doi.org/10.1111/j.1540-6261.1997.tb03806.x

Davis, J. L.; Fama, E. F.; French, K. R. 2000. Characteristics, covariances, and average returns: 1929 to 1997, Journal of Finance 55: 389-406. http://dx.doi.org/10.1111/0022-1082.00209

Dimson, E.; Nagel, S.; Quigley, G. 2003. Capturing the value premium in the United Kingdom, Financial Analysts Journal 59: 35-45. http://dx.doi.org/10.2469/faj.v59.n6.2573

Fama, E. F.; French, K. R. 1992. The cross-section of expected stock returns, Journal of Finance 47: 427-465. http://dx.doi.org/10.1111/j.1540-6261.1992.tb04398.x

Fama, E. F.; French, K. R. 1993. Common risk factors in the returns on stocks and bonds, Journal of Financial Economics 33: 3-56. http://dx.doi.org/10.1016/0304-405X(93)90023-5

Foran, J.; Hutchinson, M.C.; O’Sullivan, N. 2015. Liquidity commonality and pricing in UK equities, Research in International Business and Finance 34: 281-293.

http://dx.doi.org/doi:10.1016/j.ribaf.2015.02.006

Gallagher, D.; Ignatieve, K. 2010. Industry concentration and stock returns: Australian evidence, Working Paper. University of Technology.

Gallagher, D.; Ignatieve, K.; McCulloch, J. 2014. Industry concentration, excess returns and innovation in Australia, Accounting and Finance 55(2): 443-466. http://dx.doi.org/10.1111/acfi.12074

Garlappi, L.; Yan, H. 2011. Financial distress and the cross-section of equity returns. Journal of Finance 66: 789-822. http://dx.doi.org/10.1111/j.1540-6261.2011.01652.x

Gregory, A.; Harris, D. F.; Michou, M. 2001. An analysis of contrarian investment strategies in the UK, Journal of Business Finance and Accounting 28: 1192-1228.

http://dx.doi.org/10.1111/1468-5957.00412

Hawanini, G.; Keim, D. 2000. The cross-section of common stock returns: a review of the evidence and some new findings, security market imperfections in worldwide equity markets. New York, NY: Cambridge University Press.

Hon, M.; Tonks, I. 2003. Momentum in the UK stock market, Journal of Multinational Financial Management 13: 43-70. http://dx.doi.org/10.1016/S1042-444X(02)00022-1 
Hou, K.; Robinson, D. 2006. Industry concentration and average stock returns, Journal of Finance 61: 1927-1956. http://dx.doi.org/10.1111/j.1540-6261.2006.00893.x

Hung, D. C-H.; Shackleton, M.; Xu, X. 2004. CAPM, higher co-moment and factor models of UK stock returns, Journal of Business Finance \& Accounting 31: 87-112.

http://dx.doi.org/10.1111/j.0306-686X.2004.0003.x

Jegadeesh, N. 1990. Evidence of predictable behavior of security returns, Journal of Finance 45: 881-898. http://dx.doi.org/10.1111/j.1540-6261.1990.tb05110.x

Jegadeesh, N.; Titman, S. 1993. Returns to buying winners and selling losers: implication for stock market efficiency, Journal of Finance 48: 65-91. http://dx.doi.org/10.1111/j.1540-6261.1993. tb04702.x

Lewellen, J. 1999. The time-series relations among expected return, risk, and book-to-market, Journal of Financial Economics 54: 5-43. http://dx.doi.org/10.1016/S0304-405X(99)00030-6

Liu, W.; Strong, N.; Xu, X. G. 1999. The profitability of momentum investing, Journal of Business Finance and Accounting 26: 1043-1091. http://dx.doi.org/10.1111/1468-5957.00286

Malin, M.; Veeraraghavan, M. 2004. On the robustness of the Fama and French multifactor model: evidence from France, Germany, and the United Kingdom, International Journal of Business and Economics 3: 155-176.

Michou, M.; Mouselli, S.; Stark, A. 2007. Estimating the Fama and French factors in the UK - an empirical review, Working Paper. Manchester Business School.

Miles, D.; Timmermann, A. 1996. Variation in expected stock returns: evidence on the pricing of equities from a cross-section of UK companies, Economica 63: 369-382.

http://dx.doi.org/10.2307/2555012

Sivaprasad, S.; Muradoglu, Y. 2009. An empirical test on leverage and stock returns [online]. Available from Internet: http://ssrn.com/abstract=1031987

Strong, N.; Xu, X. G. 1997. Explaining the cross-section of UK expected stock returns, British Accounting Review 29: 1-23. http://dx.doi.org/10.1006/bare.1996.0030 


\section{APPENDIX}

\section{Description of industries classification}

Datastream classifies each company into an industry based on the firm's primary business activity published by the FTSE Actuaries. There are a total of six levels of industrial classifications. Throughout this study, we use the most detailed level 6 classification consisting of 82 industries.

Table 7. Industries name

\begin{tabular}{|c|c|c|}
\hline Aerospace & Exploration \& Prod. & Paper \\
\hline Airlines & Farming \& Fishing & Personal Products \\
\hline Alt. Electricity & Fixed Line Telecom. & Pharmaceuticals \\
\hline Alternative Fuels & Food Products & Plat.\& Precious Metal \\
\hline Apparel Retailers & Food Retail, Wholesale & Publishing \\
\hline Auto Parts & Footwear & Recreational Products \\
\hline Biotechnology & Forestry & Recreational Services \\
\hline Brewers & Furnishings & Renewable Energy Eq. \\
\hline Broadcast \& Entertain & Gas Distribution & Restaurants \& Bars \\
\hline Broadline Retailers & General Mining & Semiconductors \\
\hline Building Mat.\& Fix. & Gold Mining & Soft Drinks \\
\hline Bus.Train\& Employment & Healthcare Providers & Software \\
\hline Business Support Svs. & Heavy Construction & Spec. Consumer Service \\
\hline Clothing \& Accessory & Home Construction & Specialty Chemicals \\
\hline Coal & Home Improvement Ret. & Specialty Retailers \\
\hline Comm. Vehicles, Trucks & Hotels & Telecom. Equipment \\
\hline Computer Hardware & Industrial Machinery & Tobacco \\
\hline Computer Services & Industrial Suppliers & Toys \\
\hline Con. Electricity & Integrated Oil \& Gas & Transport Services \\
\hline Consumer Electronics & Internet & Travel \& Tourism \\
\hline Containers \& Package & Iron \& Steel & Waste, Disposal Svs. \\
\hline Defence & Marine Transportation & Water \\
\hline Delivery Services & Media Agencies & \\
\hline Diamonds \& Gemstones & Medical Equipment & \\
\hline Distillers \& Vintners & Medical Supplies & \\
\hline Divers. Industrials & Mobile Telecom. & \\
\hline Drug Retailers & Multiutilities & \\
\hline Dur. Household Prod. & Nondur. Household Prod. & \\
\hline Electrical Equipment & Nonferrous Metals & \\
\hline Electronic Equipment & Oil Equip. \& Services & \\
\hline
\end{tabular}


Nawar HASHEM is a lecturer of Finance at Damascus University, Syria. He holds a PhD in Business from the University of Greenwich, where he worked as a part-time lecturer and research fellow. His main research interests are in the areas of financial markets, asset pricing, corporate finance and governance, industrial organization, and law and economics.

Larry SU is a senior lecturer of International Business Economics at the University of Greenwich Business School. He has a passion for identifying the determinants of corporate financing decisions and international business strategies. His research has been published in Management Decision, Journal of Corporate Finance, Managerial and Decision Economics, Asian Business \& Management and Journal of International Financial Institutions and Money, among others. Much of his current research has focused on liquidity, industry structure and asset pricing, executive compensation and corporate governance, and macroeconomic conditions and capital structure. 